\title{
Audit van het milieujaarverslag
}

Drs. J.L.P. Piet

\section{$1 \quad$ Inleiding}

Er is een toenemende belangstelling voor het milieubeleid van ondernemingen. Enkele tientallen Nederlandse bedrijven brengen thans een milieujaarverslag uit om in deze inlormatiebehoefte te voorzien. Zij doen dit nog vrijwillig, maar de overheid is van plan om voor bepaalde typen bedrijven een verplichting op te leggen. Hoewel in het desbetreffende wetsontwerp niet is aangegeven welke bedrijven onder deze verplichting zullen vallen en slechts globalal is geindiceerd welke informatie moet worden verstrekt kan ik me hiervan wel een voorstelling maken. Het zal gaan om bedrijven die het milieu zwaar belasten, met andere woorden activiteiten hebben die gepaard gaan met invloed op het milieu door onttrekking of toevoeging van stoffen, of die op andere wijze de leefbaarheid van de alarde voor de mens verminderen.

Milieu is een van de grote maatschappelijke problemen van deze tijd. Daarom wordt van alle groeperingen verwacht dat zij de milieubelasting ${ }^{\prime}$ verminderen en bestaande aantastingen zoveel mogelijk saneren. Bedrijven kunnen hieraan een belangrijke bijdrage leveren door hun eigen milieubelasting te beheersen. Maar ook kunnen zij aan de oplossing bijdragen door aanpassing van het inkoop-en produktbeleid. Op deze wijze kan

Drs. J.L.P. Piet, MBA RA, is werkzaam als milieu-accountant bij Deloitte \& Touche en lid van de European Directing Board van D\&T Environmental Management and Auditing. Daarnaast is hij oprichter, bestuurder en docent van het Wetenschappelijk Instituut voor Milieumanagement (Universiteit van Amsterdam). de belasting worden verminderd die elders in de bedrijfskolom optreedt. Milieu wordt daarmee een belangrijk onderdeel van het bedrijtsbeleid.

Nieuwe doelen worden gekozen, nieuwe organisatiestructuren worden opgezet en nieuwe beheersingsinstrumenten zijn nodig on te waarborgen dat deze doelen worden bereikt. Het bedrijfsinterne milieuzorgsysteem zal moeten worden aangevuld met een goede administratieve organisatie en bestuurlijke milieu-informatie, populair gezegd: met een 'milieuboekhouding'.

Het milieujaarverslag is een geschikt instrument om milieu-informatie aan andere groeperingen te verstrekken en met hen te communiceren. De lezer wil weten hoe het bedrijf met zijn maatschappelijke verantwoordelijkheid omgaat. Het milieujaarverslag heeft naast het verstrekken van informatie tevens een functie in het afleggen van verantwoording. Het bedrijf wil daarentegen graag een boodschap uitdragen om het vertrouwen te wekken of om anderen te beïnvloeden; het verslag kan dus ook een communicatiefunctie vervullen. Zoals de grotere ondernemingen jaarlijks een gedrukt jaarverslag uitbrengen met de jaarrekening zal ook het milieujaarverslag een belangrijke functic in de 'public relations' kunnen vervullen. Wellicht ook dat in de toekomst beide verslagen in één band zullen verschijnen.

Controle van een verslag door een onafhankelijke accountant zal voor de lezer de geloofwaardigheid van het verslag vergroten. Hoewel een wettelijke controleplicht voor het milieujaarverslag niet is beoogd kan deze in een behoefte voorzien. De eerste verificaties zijn immers in praktijk al uitgevoerd. De vraag die ik in dit artikel wil beantwoorden is welke voorwaarden 
aan de accountantscontrole van het milieujaarverslag moeten worden gesteld. Mijn bedoeling is om daarmee een kader te scheppen voor effectieve en betrouwbare milieuverslaggeving met een vergelijkbare kwaliteit als het door een accountant gecontroleerde financiële verslag.

Als uitgangspunt van mijn betoog kies ik de stelling dat de controle van een milieujaarverslag alleen mogelijk is bij de anwezigheid van $1^{\circ}$ een goed milieuverslag, $2^{\circ}$ een goede, controleerbare administratie en administratieve organisatie en $3^{\circ}$ een goede auditor. In deze volgorde zal ik deze kwaliteitsvereisten behandelen. De analyse steunt zowel op theorie als op praktijkervaring met de verificatie van het milieujaarverslag.

\section{Kwaliteit van het milieujaarverslag}

Het begrip milieujaarverslag wil ik graag ruim definiëren: een jaarlijkse rapportage waarin een getrouw beeld wordt gegeven van het milieubeleid van een bedrijf en de uitkomsten daarvan. Naast dit verslag zijn andere mogelijkheden van informatieverschaffing en communicatie over de milieu-aspecten van de bedrijfsvoering mogelijk. Over kortere perioden dan een jaar worden veelal technische emissiegegevens ingezonden naar de vergunningverlener. Ook kan door middel van een logo op het produkt of op het briefpapier worden aangegeven dat aan bepaalde milieu-eisen is voldaan. De communicatie met buurtbewoners vindt vaak plaats op een 'open dag'. Elke vorm heeft eigen voor- en nadelen; daarom zullen meerdere vormen naast elkaar kunnen bestaan. Het milieujaarverslag zoals wij dit behandelen is bestemd voor meerdere groepen van anonieme lezers (Coming Clean 1993, pag. 29): werknemers. aandeelhouders, media, milieugroeperingen, financiële wereld. afnemers, overheden, kortom het 'publiek'.

De kwaliteit van het verslag moet worden afgeleid vanuit de doelstellingen ervan. Het milieujaarverslag kan meerdere functies vervullen:

- verantwoordingsdocument;

- informatie- en communicatiemiddel; en

- beleidsinstrument van de overheid.

De eerste functie vloeit voort uit het feit dat de gebruikers van deze informatie belang hebben bij een goed milieu en dat het bedrijf in staat is de milieubelasting van de eigen produktie en die van andere producenten of consumenten te verminderen. Het bedrijf is naar de samenleving toe mede verantwoordelijk voor de milieubelasting en de oplossing van het milieuprobleem. Informatie die naar 'belanghebbenden' wordt gestuurd heeft daarmee het karakter van een verantwoording. In het kader van de tweede functie kan met behulp van informatie bij anderen een beeld worden opgeroepen van het milieubeleid van de onderneming en de uitkomsten ervan. Bij communicatie gaat het om een interactief proces van uitwisseling van gedachten om een gemeenschappelijke visie te vormen over hoe de partijen met elkaar zullen omgaan. Het milieujaarverslag kan in deze interactie als communicatiemiddel worden gebruikt. Het bedrijf heeft wellicht de neiging zich in de verslaggeving iets beter te presenteren dan feitelijk juist is. Om het vertrouwen in de kwaliteit van de informatie voor de lezer te waarborgen kan de controle door een onafhankelijke accountant worden toegepast. Bij de derde, de instrumentele functie, wordt de wettelijke verplichting voor het uitbrengen van een milieujaarverslag als instrument in het overheidsbeleid gebruikt om de milieuzorg in bedrijven te stimuleren. Deze functie heeft slechts korte tijd betekenis en wij laten deze hier verder buiten beschouwing.

De kwaliteit van het milieujaarverslag is de mate waarin het verslag voldoet aan de informatiebehoefte van de lezer en de mate waarin bij deze lezer een waar en getrouw beeld wordt opgeroepen. Door middel van een informatiebehoeftenanalyse en een informatie-analyse kan dit worden bepaald. Elk bedrijf heeft zijn eigen kenmerkende vormen van milieubelasting. Bij de ene onderneming treden emissies naar de lucht op. terwijl een ander bedrijf veel gevaarlijk afval produceert. Aldus heeft ieder bedrijf een eigen milieuprofiel. Het ontwerpen van een milieujaarverslag zal dus 'op maat' moet gebeuren. Hoewel ik een aantal kwaliteitscriteria zal noemen is er vooralsnog geen standaard voor deze vorm van verslaggeving denkbaar zoals deze in de loop van decennia wel is ontwikkeld voor de financiële verslaggeving.

Als ik mezelf verplaats in de positie van de doorsnee lezer dan zal een goed milieujaarverslag voor mij de volgende vier hoofdvragen moeten beantwoorden: 
I Wat zijn de belangrijkste milieuvraagstukken van het bedrijf?

2 Wat zijn de mogelijkheden om milieuverbeteringen aan te brengen?

3 Wat zijn de feitelijke prestaties? en

4 Wat is de oorzalak van afwijkingen?

Met de antwoorden op deze vragen wordt het voor de lezer van het milieujaarverslag mogelijk om inzicht te krijgen in het milieubeleid en de uitkomsten ervan: in de loop der jaren kan het continue verbeteringsproces in het bedrijf worden gevolgd en begrepen.

\section{Ad 1: Wat sijn de belangrijkste milieuraagstukken van het bedrijf?}

Er is een kloof tussen het milieuprobleem zoals dit maatschappelijk wordt ervaren en de invloed van een enkel bedrijf hierop. De aantasting van het milieu op een maatschappelijk niveau bestaat voornamelijk uit de uitputting van natuurlijke hulpbronnen en de verontreiniging van lucht, water en bodem door de uitstoot (emissie) van stoffen, onder meer in de vorm van afvalstoffen. Deze processen kunnen nader worden gepreciseerd in termen van klimaatverandering (onder meer door de uitstoot van $\mathrm{CO}$,) verzuring (door uitstoot van $\mathrm{SO}_{2}, \mathrm{NO}_{x}$ of $\mathrm{NH}_{3}$ ), verdroging (door gebruik van grond- of oppervlaktewater) en een reeks van andere processen. Bij deze processen zijn meestal meerdere soorten van emissies betrokken die elk in meerdere of mindere mate een invloed uitoefenen en die bovendien in de loop van de lijd aan verandering onderhevig zijn. Een enkel bedrijf levert slechts een kleine bijdrage aan het ontstaan van het milieuprobleem door gebruik van stoffen en energie uil deze hulpbronnen en door emissies.

Hoewel het milieuvralagstuk een maatschappelijk probleem is komt het toch op de bestuurstafel van de hoogste leiding terecht. De overheid en ook andere maatschappelijke groeperingen trekken zich de zorg voor het milieu alan en trachten via wetgeving, beleid of ander gedrag invloed uit te oefenen op de onderneming. Milieu wordt daarmee een strategisch issue in het bedrijfsbeleid. De directie zal daartoe in kaart moeten brengen wat de verwachtingen zijn in het maatschappelijk verkeer en hierop het eigen strategisch beleid moeten aanpassen.
Voor de bepaling van het milieuprofiel van de onderneming moet de ondernemingsleiding vooral letten op wat de 'stakeholders' als een milieuprobleem ervaren en tot uitdrukking brengen in hun veranderend gedrag. De overheid richt zich bijvoorbeeld op het gebruik en de belasting van het milieu tijdens de produktieprocessen. Deze eigen milieubelasting valn een onderneming kan door een milieuvriendelijk ontwerp van processen worden verminderd. Daarnaast wordt het bedrijf gestimuleerd ook de milieubelasting te beperken die elders in de bedrijfskolom ${ }^{2}$ kan ontstaan door het produktbeleid (het ontwerp van "schone" produkten), verpakkingsbeleid, energiebesparingsbeleid, en de bevordering van afvalpreventie en hergebruik. Werknemers zullen eisen stellen aan de directe milieu-effecten op de werkvloer. warronder de veiligheid. Buurtbewoners hebben met name last van geluidhinder, stof en stank. Afnemers zullen daarentegen meer letten op de milieu-kenmerken van een produkt maar soms ook op de mate waarin het bedrijf in het algemeen de zorg voor het milieu serieus neemt: is dit een 'groen' bedrijf? Daarnaast zijn er nog de milieubeweging en andere groeperingen die verwachtingen hebben van milieuprestaties van het bedrijf.

De ondernemingsleiding moet al deze 'issues' in kaart brengen en daarop een eigen bedrijfsmilieubeleid ontwikkelen. Tegelijkertijd komt dan vast te liggen over welke milieuvraagstukken de onderneming zal moeten rapporteren aan de stakeholders.

Ieder bedrijf krijgt aldus een eigen milieuprofiel waarin de verschillende milieu-issues al dan niet aan de orde zijn en in een bepaalde mate optreden. De bedrijven kunnen vervolgens worden gerangschikt naar de graad van de totale milieubelasting. Wat betreft de wenselijkheid van milieuverslaggeving zal met name dat bedrijf moeten rapporteren dat een hoge milieubelasting heeft en in de rapportage zal dan met name aandacht moeten worden besteed aan de zwaarste vormen daarvan. De lezer zal duidelijk moeten worden gemaakt wat het relatieve belang is van elk issue. Dit betekent dat alleen de grote "vervuilers" een milieujaarverslag moeten uitbrengen en dat daarin alleen de grote vormen van milieubelasting worden beschreven. Het dienstverlenende bedrijf BSO/Origin heeft weliswaar met een milieujaarrekening een duidelijk beeld gegeven van zijn milieubeleid maar behoort 
niet tot de categorie bedrijven die een verplicht milieuverslag moet uitbrengen.

\section{Ad 2: Wat zijn de mogelijkheden om milieuverbeteringen aan te brengen?}

Een volledige beperking van de milieubelasting is onmogelijk, en ook niet strikt noodzakelijk. ${ }^{3}$ Voor de produktie worden nu eenmaal grondstoffen en energie gebruikt en er ontstaan resten die worden geëmitteerd. Bij sommige produktieprocessen is het mogelijk gebruik te maken van ingezamelde afvalstoffen zoals glas, blik en papier. De mate waarin dit mogelijk is, is echter afhankelijk van de graad waarin inzameling wordt gerealiseerd, van de technische mogelijkheden van de produktieprocessen en van de kwaliteitseisen van het eindprodukt. Bepaalde soorten papier kunnen bijvoorbeeld niet van afvalpapier worden gemaakt, bijvoorbeeld computerpapier, omdat dit te veel stof achterlaat in de elektronische apparatuur. Ook het ontstaan van afval is niet altijd te vermijden omdat bij de kwaliteitskeuring soms zeer hoge eisen aan het fabrikaat worden gesteld, bijvoorbeeld bij de produktie van voedingsmiddelen of van medicijnen.

Ook het tijdstip waarop verbeteringen uitvoerbaar zijn kan een beperking opleveren. Er zijn bepaalde 'natuurlijke' momenten om een milieuverbetering uit te voeren. Zodra een machine is versleten en een investering wordt gedaan in een nieuwe, zal bij de investeringsselectie ook rekening kunnen worden gehouden met de huidige en toekomstige milieuwensen. Deze strategische beslissingen zijn ook uit oogpunt van milieuzorg van groot belang. Uiteraard kan de slechte milieuprestatie van een produktielijn aanleiding zijn om een vervanging te vervroegen, maar bij geplande vervangingen zal het milieu-aspect ten minste in de beoordeling moeten worden betrokken. Een ander voorbeeld van een milieuverbetering op een natuurlijk moment is het herstel van eerder opgetreden milieuschade. Zodra een pand wordt gesloopt is er een geschikte aanleiding om tegen relatief lage kosten een bodemverontreiniging te saneren. De wetgeving over bodembescherming sluit hierop thans ook aan.

In het milieujaarverslag moet worden uiteengezet waar de belangrijkste verbeteringen mogelijk zijn, op welk tijdstip en waarom elders (nog) geen verbetering mogelijk is. Het strategisch milieubeleid van de onderneming wordt in concrete onderdelen en niveaus beschreven. Daarbij kan worden gerefereerd aan algemene milieuprogramma's van branche-organisaties zoals ICC, CEFIC, of het Responsible-Care-programma. Ook naar algemeen aanvaardbare milieumanagementsystemen kan worden verwezen, zoals EMAS of BS 7750. In een algemene uiteenzetting kan - vertellend worden gemotiveerd wat de relatie is tussen milieuproblemen en de kernactiviteiten van het bedrijf. Daarnaast kunnen de doelstellingen cijfermatig in de tijd worden geprojecteerd.

\section{Ad 3: Wat zijn de feitelijke prestaties?}

Het milieujaarverslag bevat van alle thema's van het bedrijfsmilieubeleid naast de streefcijfers ook de feitelijke prestaties. Van de verschillende milieu-issues worden gegevens verzameld van de bereikte uitkomsten. Deze gegevens worden verwerkt tot begrijpelijke informatie. Hiervoor kunnen naast de feitelijk verbruiks- en emissiegegevens ook kengetallen worden gehanteerd waarin het prestatie-element goed tot uitdrukking komt: de zogenoemde milieuprestatie-indicatoren of EPI's. ${ }^{4}$ Voorbeelden van deze kengetallen zijn:

- emissiereductiepercentages;

- index van emissie per ton produkt;

- aandeel gerecycleerde grondstoffen;

- afkeurpercentage;

- waterverbruik per ton fabrikaat.

Met tekst wordt deze kengetallen nader toegelicht en inzicht gegeven in het beleid en de uitkomsten ervan.

De milieuprestatie-indicatoren zijn weliswaar geschikt om een beeld te vormen van de milieuprestaties van de onderneming. Gezien de hierboven genoemde beperkingen in de mogelijke milieuverbeteringen is het vooralsnog niet zinvol om vergelijkingen te treffen tussen bedrijven. Benchmarking is dus nog niet mogelijk. Evenmin zijn er harde normen. In het milieujaarverslag wordt de uitkomst gerefereerd aan de interne normen die voortkomen uit het bedrijfsmilieubeleid. Dit beleid dient daarom zodanig te worden beschreven dat de lezer dit kan beoordelen in het licht van de maatschappelijke urgentie. Een bedrijf dat een matig milieubeleid voert zal het risico lopen dat vanuit de samenleving commentaar wordt geleverd op het lage gehalte. 


\section{Ad 4: Wat is de oorzaak ran afwijkingen?}

De kengetallen brengen zowel het goede als het slechte nieuws. De werkelijke uitkomsten worden namelijk afgezet tegen de cijfers van voorgaande perioden of tegen de streefcijfers. De lezer zal met genoegen kennis nemen van het goede nieuws. maar zal van de negatieve afwijkingen willen weten wat de oorzaak is. De directie is in staat een nadere verklaring te geven van de opgetreden afwijkingen.

Behalve deze vier hoofdvragen kunnen andere onderwerpen bijdragen tot een goede beeldvorming bij de lezer. Met name jegens de financiële stakeholders kan een nadere uiteenzetting worden gegeven over de financiële gevolgen van dit milieubeleid. Er is een logische samenhang tussen het financiële aspect en het milieu-aspect van de gang van zaken. Produktiecijfers komen in beide vormen van rapportage voor en er dient een consistentie te zijn in de rapportages. Verplichtingen, voorzieningen en kosten die samenhangen met milieu-aspecten komen zowel in het financiële verslag als in het milieuverslag voor.

Behalve de beleidsonderdelen die binnen de verwachtingspatronen vallen mag de onderneming een exposé geven van de hogere visie van het bedrijfsmilieubeleid. Filosofische beschouwing over het duurzaamheidsconcept ${ }^{5}$, levenscyclusanalyse van de produkten, of andere communicatiemethoden over de plaats van de onderneming binnen het milieuprobleem kunnen het commitment van de ondernemingsleiding bij het probleem van de samenleving tonen. Het is ook niet noodzakelijk dat de leiding kritiekloos de roep uit de samenleving beantwoordt. Als op enig punt eisen worden gesteld die, vanuit de bedrijfspositie bezien, als irrationeel worden beoordeeld dan kan de leiding hiervan mededeling doen in het milieujaarverslag. Pas dan zal dit verslag een functie vervullen in de communicatie.

Samengevat moet het goede milieujaarverslag naast gegevens en cijfermatige informatie ook voldoende toelichting en uitleg bevatten om de lezer in staat te stellen inzicht te krijgen in de doelstellingen en de uitkomsten ter zake van de milieu-aspecten van de bedrijfsvoering. Ook de leiding mag haar eigen visie op de wensen van de andere groeperingen in onze samenleving uitdragen als onderdeel van een communicatieproces.

\section{Kwaliteit van de milieuboekhouding}

De administratieve organisatie van het bedrijf moet zodanig zijn opgezet dat inzichtelijke informatie kan worden samengesteld over het milieubeleid en de uitkomsten ervan. Het informatieprodukt 'milieujaarverslag' moet niet alleen de gevraagde informatie bevatten mar tevens aan andere kwaliteitseisen voldoen, zoals relevantie, betrouwbaarheid en een goede presentatievorm. De relevantie van de informatie bevat een spectrum aan kwaliteitsaspecten zoals volledigheid. toereikendheid en nauwkeurigheid. Dit stelt eisen aan het traject van meten, registreren en gegevensverwerking. Deze administratieve organisatie wordt ook wel de milieuboekhouding genoemd. Een goede milieuboekhouding is onmisbaar voor een goed milieujaarverslag.

De milieuboekhouding heeft daarnaast nog een tweede functie en die is wellicht nog belangrijker: het verschaffen van informatie alan het interne management voor het 'doen functioneren' en beheersen van de dagelijkse bedrijfsactiviteiten. Aan deze operationele activiteiten zijn milieuaspecten verbonden. De ondernemingsleiding moet doelen en streefcijfers kiezen en de bedrijfsprocessen zodanig aansturen dat de milieubelasting op een aanvaardbaar laag niveau blijft. Verder is milieu-informatie nodig over de werkelijke uitkomsten. waarbij een analyse wordt gemaakt van de verschillen met de streelcijfers en de oorzaken worden verklaard. Aldus kan de leiding met behulp van bestuurlijke informatie de bedrijfsprocessen onder controle houden en de milieuprestaties verbeteren. De milieuboekhouding is dus een belangrijk instrument voor milieuzorg.

Om mijn bedoeling duidelijk te maken wil ik het onderscheid tussen de begrippen 'gegevens' en 'informatie' ook toepassen op milieugegevens en milieu-informatie. Gegevens zijn slechts feiten, bijvoorbeeld cijfers over emissies en afvalstoffen. Informatie is meer, omdat dit het bew ust-ijn van de mens bereikt en bijdraagt tot zijn kennisbeeld (Starreveld I, 1991, pag. 18). De gebruiker van informatie moet in staat zijn te oordelen of te beslissen. Het management is met behulp van milieu-informatie in staat over de milieu-aspecten te oordelen. Voor de beeldvorming en beoordeling van de milieuprestaties is het van belang de milieubelasting te relateren aan de veroorzakende 
krachten, aan andere prestaties zoals het produktievolume of aan andere milieu-aspecten. Een voorbeeld van milieu-informatie is een afval- of emissiepercentage afgezet tegen een criterium dat is ontleend aan produktietechnische normen (werkelijk afvalpercentage $=2.1 \%$ tegen een norm van $2,4 \%$, hetgeen tot de conclusie leidt dat binnen de norm is geproduceerd). Milieugegevens zijn de bouwstenen voor milieu-informatie. maar voor deze laatste zijn ook gegevens nodig van andere aspecten. Een emissiegetal kan worden gerelateerd aan een produktiegegeven en daarna in de vorm van een indicator een beeld geven van de milieuprestaties. De milieuboekhouding is dus geen afzonderlijke administratie maar een nieuw aspect van het totale informatieverzorgend systeem.

Voor de bewaking van de interne prestaties kunnen indicatoren (EPI's) worden ontworpen. Met name in de maandelijkse interne rapportages voor het midden en hogere management, zoals deze in veel ondernemingen al gebruikelijk worden samengesteld uit omzetspecificaties, produktie-analyses en personeelscijfers, kan milieu-informatie worden opgenomen. Omdat daarbij over de verschillende milieu-issues wordt gerapporteerd wordt het ook mogelijk de milieuprestaties in de juiste context te plaatsen.

Voor de waarborging van de betrouwbaarheid van milieu-informatie kunnen in de administratieve organisatie maatregelen van interne controle worden ingebouwd. Omdat milieu een betrekkelijk nieuw aspect is zal de leiding uitgebreide instructies uitvaardigen over hoe te handelen in de verschillende omstandigheden. De naleving hiervan moet door inspectie of door interne verificatie worden vastgesteld en noodprocedures moeten worden getest. Verder kan door het scheiden van functies en/of door het leggen van verbanden een interne controle worden georganiseerd.

Evenals bij de bewaking van het financiële aspect van de bedrijfsvoering kan met behulp van het interne-controle-instrument van de functiescheiding zekerheid worden vergroot over de beheersing van milieurisico"s. Om zeker te zijn dat alle afvalstoffen op een verantwoorde wijze zijn afgevoerd - als voorbeeld - kan worden gesteund op de al dan niet reeds aanwezige scheiding tussen het bedrijfsbureau (ex ante), de produktie-afdeling (ex post), bewaarder van afvalstoffen, bewaarder van eindfabrikaat (afvalstoffen en eindfabrikaat tezamen vormen een verband met het verbruik van grondstoffen) en de expeditie-afdeling. In feite is geen van deze afdelingen in staat een transactie volledig buiten de administratie te houden. Indien binnen de procedures van afvalbehandeling controlepunten worden ingebouwd zullen fouten tijdig aan het licht kunnen treden.

Ook het instrument van verbandscontrole kan worden gehanteerd, bijvoorbeeld als massabalans of als onderdeel van de receptuur. Eventuele fouten komen aan het licht als het verband niet sluit. De beperking in de toepasbaarheid van deze controle is de kleine tolerantie bij gevaarlijke stoffen, terwijl vaak ook de meetbaarheid van kleine fracties een probleem kan zijn. Uiteraard moeten de kosten van een verdergaande detaillering in de controle opwegen tegen de milieurisico's. Dit betekent dat de milieuhygiënische normen bepalend zijn voor het niveau van interne controle.

Tot slot wil ik wijzen op de krachtige controle die ontstaat door de uitgebreide interne analyse en rapportage van milieuprestaties. Een diepgaande bestudering van de bedrijfsprocessen levert nieuwe inzichten op voor de aansturing en normen.

Voor de audit van het milieujaarverslag zijn voorts enkele praktische eisen te stellen aan de milieuboekhouding, wil deze achteraf controleerbaar zijn. Van elke transactie moet een voldoende audit-trail aanwezig zijn: via nummers en andere identificaties moet een transactie heen en terug door de administratie kunnen worden gevolgd en de verschillende onderdelen van de administratie moeten onderling aansluiten. Op de bewijsstukken moeten sporen achterblijven van de uitgevoerde interne controles in de vorm van parafen. Bewijsstukken moeten vervolgens ook op een toegankelijke wijze worden bewalard. De auditor moet in staat zijn om achteraf de processen te reconstrueren.

\section{Kwaliteit van de auditor}

Vervolgens zal ik de kwaliteitseisen beschrij- 
ven van de controleur van het milieujaarverslag. De audit van de getrouwheid van een milieuverslag moet niet worden verward met de audit van de toereikendheid van het milieuzorgsysteem. Hier is niet het zorgsysteem object van audit maar het verslag, ook al wordt bij de audit gesteund op de kwaliteit van dit zorgsysteem. Het doel is bovendien een oordeel te geven over de getrouwheid en niet over de effectiviteit. Het gaat om sterk verschillende typen van auditing die ook eigen specifieke expertise verlangen. De 'scope' van de audit komt ook tot uitdrukking in de goedkeurende verklaring bij het milieujaarverslag, die zou kunnen luiden: 'Ingevolge de verstrekte opdracht hebben wij het milieujaarverslag van NVXYZ gecontroleerd. Dit onderzoek is in overeenstemming met de algemeen aanvaarde controlegrondslagen. Op grond van ons onderzoek verklaren wij dat dit verslag een getrouw beeld geeft van de milieuresultaten over 1994 in relatie tot de bedrijfsmilieudoelstellingen en ook overigens in overeenstemming is met de wettelijke bepalingen inzake milieuverslaggeving.' Ik acht het niet correct om in een milieuverslag waarin de milieuprestaties van de onderneming worden weergegeven een mededeling van een auditor op te nemen omtrent de kwaliteit van het milieuzorgsysteem omdat dit de lezer van het verslag op een verkeerd spoor zet.

De auditor van het milieujaarverslag zal niet alleen een grondige kennis en ervaring moeten hebben van de auditing-theorie in het algemeen, maar ook van de specifieke aspecten ervan in het kader van milieuverslaggeving. Het object van de audit is het verslag, dus de auditor zal verstand moeten hebben van de verslaggevingstheorie. Voor het vaststellen van de betrouwbaarheid ervan zal hij bewijs (evidence) moeten vinden in de milieuboekhouding, dus zal hij verstand moeten hebben van administratieve organisatie.

De controle-aanpak kan nauw aansluiten op de gebruikelijke methodologie in de accountantscontrole waardoor een effectieve en efficiënte uitvoering is gewaarborgd. Twee kenmerkende fasen in het controleproces wil ik hier nader belichten: de risico-analysebenadering en de afweging tussen systeemgerichte en gegevensgerichte controlemaatregelen. De risico-analyse kan ook worden toegepast bij de controle van het milieujaarverslag. Deze risico's moeten echter niet worden verward met milieurisico's. Het gaat hier om de kans dat een fout in de informatie optreedt die niet door interne controle en accountantscontrole wordt ontdekt. Het gaat dus om informatierisico's. Het volume van de geplande controlemaatregelen wordt afgeleid vanuit de geschatte kans op fouten en achteraf getoetst op toereikendheid. Hiermede kan een besparing worden verkregen ten opzichte van een volledige controle. De dosering tussen systeemgerichte en gegevensgerichte controlemaatregelen is eveneens gericht op effectiviteit en kostenbeheersing. Een goed ontworpen milieuboekhouding met veel interne controle geeft reeds een redelijke zekerheid dat de informatie die dit systeem oplevert betrouwbaar is. Beoordeling van dit systeem, waarneming van de operationaliteit ervan en vaststelling van de werking van de interne controle biedt een redelijk evidence. De werking van het systeem kan worden vastgesteld door verificatie van gegevens. Hierbij kan de steekproeftechniek worden toegepast. Verder zie $i k$ als een voordeel van de accountantscontroleaanpak de voorgeprogrammeerde kwaliteitsbewaking van de audit.

De audit van het milieujaarverslag is een 'accounting' audit. De auditor moet dus deskundig zijn in het vakgebied van accounting, met name in verslaggeving en in administratieve organisatie. De bestaande groep (register)accountants beschikt over een grondige kennis van auditing en accounting. Hij moet echter een aanvullende opleiding volgen om inzicht te krijgen in de verschillen tussen de financiële en milieu-aspecten van de bedrijfsvoering. De bestaande Nederlandse postdoctorale opleiding 'Accountant en Milieu' bevat algemene kennis van verschillende onderdelen uit de milieukunde en grondige kennis van milieumanagement en milieu-accountancy. Binnen de milieukunde wordt het referentiekader opgebouwd voor de behandeling van milieuvraagstukken door de ondernemingsleiding. Met name milieurecht, overheidsbeleid en ecologie zijn hiervoor van belang. Milieumanagement is de milieuspecialisatie van de bedrijfseconomie en bevat kennis van beheersingssystemen en verslaggeving. In het vakgebied van de milieu-accountancy wordt de expertise van de accountancy toegepast voor het oplossen van milieuvraagstukken in bedrijven. De afgestudeerde milieu-accountants zijn in staat om de deugdelijkheid (lees ook: volledigheid) van het bedrijfsmilieubeleid zelf- 
standig te beoordelen en aan te geven over welke issues moet worden gerapporteerd en in welke vorm. $\mathrm{Zij}$ zijn in staat de audit van het milieujaarverslag uit te voeren. Experts van andere disciplines die een milieuverslag willen verifiëren kunnen worden bijgeschoold door de accountantsopleiding te volgen.

De vraag wordt weleens gesteld over welke technologische kennis de milieu-accountant moet beschikken. Deze kennis kan naar mijn mening bescheiden zijn: de accountant die het financiële jaarverslag van een ziekenhuis controleert behoeft geen arts te zijn en de controleur van de jaarrekening van een kerncentrale geen kernfysicus. De milieu-accountant moet wel zoveel inzicht hebben in de technische aspecten van de bedrijfsvoering dat hij kan vaststellen welke (interne) deskundigen voor zijn audit voldoende evidence kunnen leveren. Een milieukundige mist daarentegen de kennis van informatie en bestuurlijke informatieverzorging om een 'accounting' audit te kunnen uitvoeren.

De accountant geniet een algemene maatschappelijke erkenning. Vanwege zijn onafhankelijkheid speelt hij een gewaardeerde rol bij de controle van financiële verslagen die bestemd zijn voor anonieme aandeelhouders en andere derden-belanghebbenden (third party audit). Ook het milieujaarverslag is een verantwoordingsdocument in het verkeer met derden. Het zou een goede zaak zijn deze vertrouwenspositie van de accountant ook hier te benutten. Om geen verwachtingskloof te laten ontstaan is een adequate opleiding van de milieu-accountant noodzakelijk.

\section{Samenvatting en conclusies}

Het accountantsberoep heeft in meer dan 100 jaar financiële verslaggeving een respectabele praktijk en theorie opgebouwd van het vakgebied van de accountancy. De kennis van de administratieve organisatie, de inrichting van de verslaggeving en de audit van dit verslag zijn op een zodanig hoog niveau gekomen dat deze kunnen worden toegepast op andere vormen van verslaggeving. Mogelijk kan het milieujaarverslag zich nu in enkele jaren tot een volwaardig informatieprodukt ontwikkelen als deze expertise hiervoor wordt ingezet. Het maatschappelijk verkeer zal, vergelijkbaar met de accountantscontrole van het financiële verslag, een groter vertrouwen stellen in het milieujaarverslag indien dit van een goedkeurende accountantsverklaring is voorzien. Ten behoeve van de controleerbaarheid van dit milieujaarverslag heb ik kwaliteitseisen geformuleerd voor dit verslag, voor de onderliggende milieuboekhouding en voor de auditor. De voorwaarden voor accountantscontrole van het milieujaarverslag wil ik onderstaand samenvatten.

Het milieujaarverslag is een beleidsverslag waarin met behulp van hoogwaardige milieuinformatie een beeld wordt gegeven van het milieubeleid van een bedrijf en uitkomsten ervan. Het is geen technische rapportage met milieugegevens omdat deze geen beeld oproept bij de lezer; een milieujaarverslag moet milieu-informatie bevatten. Uitgaande van de informatiebehoefte van de lezers enerzijds en van de behoefte van de bedrijfsleiding om een boodschap uit te dragen anderzijds zal per bedrijf de inhoud van het milieujaarverslag kunnen worden bepaald. In het verslag wordt de milieuprestatie in cijfers en woorden weergegeven. De uitkomsten worden afgezet tegen de gestelde doelen, en afwijkingen worden verklaard. De kwaliteit van het verslag is de mate waarin de lezer inzicht krijgt en overtuigd raakt van het commitment van de leiding, de getrouwheid van de weergave en de toereikendheid van de mededelingen in de specifieke bedrijfssituatie in het licht van het maatschappelijke milieuvraagstuk.

Bij de controle van het milieujaarverslag zal de auditor zowel gegevens- als systeemgericht te werk gaan. Zijn aanpak wordt daarbij beïnvloed door de kwaliteit van de administratieve organisatie en de beschikbaarheid van ander 'evidence', bijvoorbeeld door interne controle gewaarmerkte bewijsstukken. De verificatie is steeds 'accounting' georiënteerd. De administratieve organisatie en interne controlemaatregelen van milieurelevante bedrijfsprocessen dienen zodanig te zijn opgezet dat milieugegevens beschikbaar zijn en dat milieu-informatie toereikend en betrouwbaar is. Deze $\mathrm{AO} / \mathrm{IC}$ is een onmisbaar onderdeel van het milieuzorgsysteem. Van alle bedrijfstransacties zal een voldoende bewijs worden bewaard zodat de werking van de interne controle over de milieurelevante bedrijfsprocessen ook achteraf kan worden vastgesteld. 
De verificatie van het milieujaarverslag valt binnen de expertise van de accountant. mits deze zich heeft bijgeschoold ter zake van milieuvraagstukken. Kennis van auditing, verslaggeving en administratieve organisatie zijn onmisbaar voor de controle van 'accounting' georiënteerde verslagen. Deze accountant zal echter nadere algemene kennis moeten hebben van de grondslagen van milieukunde om het milieu-aspect te kunnen herkennen en beoordelen. De gespecialiseerde milieu-accountant beschikt thans als enige professional over de vereiste kennis. Bovendien geniet hij het vertrouwen van het maatschappelijk verkeer ter zake van voor derden bestemde beleidsverslagen.

\section{I T E R A T U U R}

Eckel, L., K. Fisher, G. Russel, (1992), Environmental Performance Measurement, CMA Magazine, maart, pp. 16-23

Deloitte Touche Tohmatsu International, IISD, SustainAbility, (1993), Coming Clean, corporate environmental reporting, London.

European Green Table, (1993), Environmental Performance Indicators in Industry - Draft Handbook, Oslo.

Piet, J.L.P., (1995), Rekenschap en milieuzorg, de ontwikkeling van het milieu-accountancy, Amsterdam.

Piet, J.L.P., (1994), Milieu-auditing, Handboek Accountancy, hoofdstuk D 1450 (pp. 3-29), Alphen a/d Rijn.

Starreveld, R.W., (red.), (1991), Bestuurlijke informatieverzorging, deel 1, Algemene grondslagen, Alphen a/d Rijn.

Stavenuiter, J.A.M., (1995), Het (wettelijk) milieuverslag controleerbaar?, De Accountant, februari, pp. 389-392.

VNO/NCW, (1990), Milieurapportage door bedrijven, Den Haag.

Verenigde Naties, (1989), Rapport van de Universele Commissie voor Milieu en Ontwikkeling, Onze aarde morgen, Tiel (vertaling van het 'Brundtland-rapport', Our common Future, 1987)
Verenigde Naties, Economic and Social Council, Information disclosure relating to environmental measures, E/C.10/ AC.3/1990/5.

Ministeries van Volkshuisvesting, Ruimtelijke Ordening en Milieubeheer 'VROM', Economische Zaken en Landbouw, Natuurbeheer en Visserij, (1989), Nationaal Milieubeleidsplan (NMP), vergaderstuk Nr. 21137 Tweede Kamer der Staten-Generaal, 's-Gravenhage.

Ministeries van Volkshuisvesting, Ruimtelijke Ordening en Milieubeheer en van Verkeer en Waterstaat, (1989), Tweede Kamer Notitie, vergaderjaar 1988-1989, Nr. 20 633, Bedriffsinterne Milieuzorg, 's-Gravenhage.

Zuidhollandse Milieufederatie, (1995), Handleiding Milieujaarvers/agen, Rotterdam.

\section{N O T E N}

1 Milieubelasting is de invloed van activiteiten op het milieu die bijdraagt tot het ontstaan van milieuproblemen (niet te verwarren met ecotax)

2 In het milieubeleid van de overheid wordt hier gesproken over de 'keten'. Een bedrijf kan invloed hebben op de milieueffecten die elders in de keten ontstaan. Door het hergebruik van afvalstoffen kan een keten worden omgebogen tot een kringloop.

3 De natuur bezit een zeker herstelvermogen waardoor lage vormen van belasting aanvaardbaar zijn. Aan een bos kan 'duurzaam' hout worden onttrokken als de omvang van de kap niet groter is dan de natuurlijke aangroei. Het zogenaamde GFT-afval kan via compostering worden gebruikt als voedingsstof voor de bodem.

$4 \mathrm{EPI}$ is een afkorting van Environmental Performance Indicator.

5 Het concept van de 'duurzame ontwikkeling' of 'sustainable development' is ontleend aan het Brundlandt-rapport. Dit is de situatie die over enkele generaties moet zijn bereikt waarin de mens kan leven van de beschikbare natuurlijke hulpbronnen en waarin de milieubelasting zo laag is dat deze onder het natuurlijk herstelvermogen van de natuur blijft. 